熱分析操作が正しく，また分析中成分変化のないことを証明して いる。これは熱分析前後の成分割合が，化学分析の結果ほとんど 同じである事実と一致している。

前報の結果と比較して大分異なる結果をえたが，ての大きな原 因は, 変曲点の判定, 過冷現象および塩中の水分, 炭酸ナトリウ 么等の不純物の影響と考えられる。 $\mathrm{NaOH}$ 中の水分除去と炭酸 ナトリウム生成防止は，窒素ガスを送入してもなかなか困難なる のである。変曲点の判定は示差曲線により, 過冷現象による誤差 は泠却速度をつとめて遅くすることによって訂正できたと考えら れる。

本法による金属ナトリウム製造は, 陽極アマルガムの蒸気圧を 低くするため，低温での操作が望ましい。したがって 3 成分共晶 組成を使用するのが最適であるが, 工業的見地から高価な $\mathrm{NaI}$ 成分をなるべく少なくしたい。一方，金属ナトリウムは必然的に 酸化ナトリウムになるから，これを水酸化ナトリウムに変えて， 電解に害を与える酸化ナトリウムの存在量を少なくする必要があ る。前述のようにこのため電解中水素ガスを槽内に送入して，こ
れを水酸化ナトリウムに変化させる。

本 3 元系平衡状態図のみから考察すると, 共晶成分より $\mathrm{NaI}$ 成 分の少ない部分は, 融点温度分布の斜傾が比較的ゆるく, 浴組成 が $\mathrm{NaOH}$ 成分の多い方に変化して行っても，融点の上昇が少な いから，前述の組成変化に応じる温度調節も非常に容易である。 一方, 高価な NaI 成分の少ない長所もある。この研究結果から 考察すると $\mathrm{NaOH} 71 \mathrm{~mol} \%, \mathrm{NaBr} 10$ 15 mol\% 成分のもの が最適と考えられる。しかし他の条件も考虑して決定すべきもの であろう。

\section{4. 結言}

実際の電解に役立たせるように，示差熱分析により新に測定者 をかえて, $\mathrm{NaOH}, \mathrm{NaBr}$ 扎よび $\mathrm{NaI} 3$ 成分の共晶点付辺の混 合塩について平衡状態図を詳細に作成した。そしてその際生成す ると考えられる固溶体，分子間化合物について検討した。求めら れた結果は文献の值および前回の值と大分異なる結果をえた。

（昭和 28 年 9 月, 電気化学会関西支部講演会講演）

\title{
炭 化チタンの生成反応過程
}

(昭 和 31 年 8 月 21 日受理)

中 川雅 直*

\section{緒㫠}

炭化チタン $\mathrm{TiC}$ の製法1)は気相, 固相および液相反応法2)等さ まざまである。これらの諸方法のうち工業的に利用されているの は主として固相反応法であり，それに使用される炬はアーク炉， 水素炉ならびに真空炬3)等で, 原料としては $\mathrm{TiO}_{2}$ と $\mathrm{Ti}$ のいず れかが用いられる。

これらの諸方法の中で純度の高い $\mathrm{TiC}$ を経済的につくるため には $\mathrm{TiO}_{2}$ を原料とし，連続操業のできるような真空炉を使用す る方法が最る有利であると考える。

真空中または低圧の $\mathrm{CO}$ 中に抢ける $\mathrm{TiC}$ の生成機構について は Meerson $\left.{ }^{4}\right)$ らの研究がある。同氏らは $1300 \sim 1500^{\circ} \mathrm{C}$ におい て $\mathrm{TiO}_{2}$ と $\mathrm{C}$ の混合物を㸁成し，その焼成物について検討した 結果, 真空中に拈ける生成物は $\mathrm{TiC}-\mathrm{Ti}$ の固溶体であり, 100 $\mathrm{mmHg}$ では TiC-TiO-Ti の固溶体がえられ，中間の 1 およひ $10 \mathrm{mmHg}$ のとき $\mathrm{Ti}$ および TiO の少ない TiC ができること， ならびに TiC が生成する過程で CO が還元作用を行っているこ と,さらに 1600 および $1700^{\circ} \mathrm{C}$ の平衡組成の計算値等を報告し ているがその詳細は明らかでない。

* 東京工業試験所：東京都渋谷区.

1) Gmelins Handbuch der anorganischen Chemie 8 Auflage, Titan S. 358 (1951).

2) P.M. Mckenna, U.S. 2, 515, 463 (1950); Chem. Abst. 44, 8850 (1950).

3) C.G. Goetzel, Treatise on Powder Metallurgy, vol. II p. 87 (1950) Interscience Publishers Inc, New York.

4) G.A. Meerson, O.E. Krien, Zhur. Priklad. Khim. 25, 134 (1952); Chem. Abst. 47, 4705 (1953).
Hüttig ${ }^{5)}$ は低圧の $\mathrm{H}_{2}$ 中で $\mathrm{TiO}_{2}$ と $\mathrm{C}$ の混合物から $\mathrm{TiC}$ を つくるときには急速に温度を上犁したほうが純度の高いものがで きると述べている。そのような事実があるならばその理由として は $\mathrm{H}_{2}$ が $\mathrm{TiO}_{2}, \mathrm{Ti}_{2} \mathrm{O}_{3}$ 扰よび $\mathrm{TiO}$ 等の酸化物あるいは $\mathrm{C}, \mathrm{TiC}$ 等と反応すること,ならびにCによる還元過程が加熱速度によっ て変わってくること, の二つが考えられる。同様な理由から本研 究の場合のような低圧の $\mathrm{CO}$ 中においても, 加熱速度によって 反応過程が変わってくる可能性のあることが考えられる。

本研究は低圧の $\mathrm{CO}$ 中に拈いて $\mathrm{TiO}_{2}$ と $\mathrm{C}$ とから $\mathrm{TiC}$ が生 成する際の反応過程を検討することを目的としたが，本反応の中 間生成物は TiO-Ti-TiC の 3 元固溶体であるのでX線解析によ る生成物の組成の解析は困難であり，また酸素を含めた完全分析 る困難なため, 反応速度の面から検討を行った。すなわち本研究 においては低圧の CO 雾囲気中において反応温度, 加熱速度, $\mathrm{TiO}_{2}$ と $\mathrm{C}$ の配合比および $\mathrm{CO}$ 圧を変化したときの $\mathrm{TiC}$ の生 成反応過程を加熱減量曲線および結合炭素量の両面から調べ， あ わせて 1600 および $1800^{\circ} \mathrm{C}$ に打ける生成物の平衡組成（結合炭 素百分率) の実測值を求めた。その結果加熱速度によって反応径 路に変化が起ることが推定でき，またCO圧をかえることによっ て反応過程に打いて CO が反応に関係しているために生じたと考 えられる現象を認めたので，これらの実験事実について検討した 結果を報告する。

\section{実 験 方 法}

試料 帝国化工製の Anatase 型 $\mathrm{TiO}_{2}$ と電気化学製アセチレ ンブラックを使用した。 $\mathrm{TiO}_{2}$ は $110^{\circ} \mathrm{C} て ゙ 2$ 時間乾燥して用い,

5) G. F. Hüttig, Z. anorg. allgem. Chem. 270, 33 (1952). 
アセチレンブラックは磨り合わせのよい蓋付黒鉛ルッボに入れ， それをコークス粉末中に埋めて $900^{\circ} \mathrm{C} に 30$ 分焼成して使用した。 この兩者を $\mathrm{C} / \mathrm{TiO}_{2}$ のモル比が $2.8,2.9,3.0,3.2$ および 4.0 になるように秤取し、メノウ乳鉢で $\mathrm{TiO}_{2}$ がいちよ5に分散する まで十分混合し，その 3.5〜 $4 \mathrm{~g}$ をとってトルェンで5るおし，鉄 型に入れて手圧により径 $20 \mathrm{~mm}$, 高さ $13 \sim 14 \mathrm{~mm}$ の円筒状に 成型し, $110^{\circ} \mathrm{C} て ゙ 2$ 時間乾燥後烧成に供した。使用した $\mathrm{TiO}_{2}$ 中 には $\mathrm{SiO}_{2}, \mathrm{CaO}$ および $\mathrm{MgO}$ 等は定量できる程度には存在しな かった。またその真比重は $3.880 \mathrm{~g} / \mathrm{cc}$ であり, 格子定数からの 計算值 $\left.{ }^{6}\right) 3.87 \mathrm{~g} / \mathrm{cc}$ とよく一致していた。アセチレンブラックの 灰分は $0.2 \%$ であった。

焼成および加欮隇母曲線の測定 試料を内径 $21 \mathrm{~mm}$, 外径 25 $\mathrm{mm}$ の黒鉛ルツボに入れ, 試料上に厚さ約 $2 \mathrm{~mm}$ の黒鉛の薄板 をのせたのち内径 $40 \mathrm{~mm}$ または $50 \mathrm{~mm}$ の黒鉛管発熱体を有す る真空電気炉中で焼成した。

$\mathrm{CO}$ 圧は 1, 5, 20,40, $100 \mathrm{mmHg}$, 加熱速度は 50, 100, $150,200,300^{\circ} \mathrm{C} / 5 \mathrm{~min}$, 焼成温度は $1200 \sim 2000^{\circ} \mathrm{C}$ の範囲でほぼ $100^{\circ} \mathrm{C}$ 間隔とした。焼成に際しては圧力を $0.1 \mathrm{mmHg}$ 程度に保 って $800^{\circ} \mathrm{C}$ まで約 40 分で温度を上昇し, それから CO を炉中 に導入して所定圧力とし, 所定圧力を保つよ 5 に排気速度を調節 しながら所定の速さで温度を上昇した。ここで使用した COは $\mathrm{HCOOH}$ を熱濃硫酸に注いでつくったものをソーダ石灰および $\mathrm{P}_{2} \mathrm{O}_{5}$ で精製したものである。温度測定には補正を施した光学高 温計を使用し,輻射およびのぞき空の吸収に対する補正を行った。

加熱減量曲線の測定には前と同じ試料を同じ黒鉛ルッボに入れ， タングステン線で $12 \mathrm{~mm} / \mathrm{g}$ の感度を有するピアノ線製スプリン グにつるし，温度上昇は前述と同様に行い，CO 圧を $5 \mathrm{mmHg}$ に保ち，カセトメーターでスプリングの収縮を $1 / 20 \mathrm{~mm}$ まで読 んで減量と温度との曲線を求めた。減量は $\mathrm{TiO}_{2}+3 \mathrm{C}=\mathrm{TiC}+$ $2 \mathrm{CO}$ の変化に相当する值を $100 \%$ と表示した。

なお烧成および加熱减量曲線の測定は $2 \sim 3$ 回行った。以下に 掲げる加熱減量曲線は 2 回の測定点の平均の点を連ねたものであ る。

分析方法 ${ }^{7)}$ 焼成物をメノウ乳鉢で粉砕， $110^{\circ} \mathrm{C}$ で 2 時間乾燥 後その $0.1 \mathrm{~g}$ を白金ボートにとり, 元素分析と同様にして全炭素 量を求めた。 $\mathrm{CO}_{2}$ の吸収にはソーダ石綿を用いた。また同一試料 $1 \mathrm{~g}$ を白金皿にとり, 水冷しながら濃硝酸 $15 \mathrm{cc}$ を加え, 分解が ゆるやかになったら徐々に加温し, 時々 HF を少量ずつ加えて完 全に分解し, 飽和 $\mathrm{H}_{3} \mathrm{BO}_{3}$ 溶液 $15 \mathrm{cc}$ を加えて少しく加温してか ら冷却, 酸処理後強熱した石綿を口層としてグーチルッボでロ過 し，乾燥後黒鉛の付着した石綿を白金ボートにとり，前述と同じ 方法でCの分析を行い, 遊離炭素量を求めた。全炭素百分率から 遊離炭素百分率を差引いた值を結合炭素百分率とした。以下に揭 げる分析值は同一条件で焼成した $2 \sim 3$ コの試料の分析值の平均 であり, 同一条件における焼成物の分析值は $\pm 0.1 \%$ の範围でよ く一致した。

なお結合炭素の理論值は $20.05 \%$ である。また結合炭素が 19.6 $\%$ の焼成物を Cu の対陰極を用いてX線粉末写真をとり，Cu の $K_{\alpha}$ による回折因からえた格子定数は $4,318 \AA$ であり, その值

6) Gmelins Handbuch der anorganischen Chemie, 8 Auflage, Titan, S. 240 (1951).

7) W. O. Touhey, J.C. Redmond, Analytical Chem. 20, 202 (1948).
は Krainer ${ }^{8)}$ らの報告とよく一致しているので前述の分析方法 によってえた結果は相当信頼できるすのと思われる。

\section{実験結果および考察}

第 1 図に加熱速度を $100^{\circ} \mathrm{C} / 5 \mathrm{~min}, \mathrm{CO}$ 圧を $5 \mathrm{mmHg}$ とした ときの焼成時間と減量の関係を示す。同図から $1300 \sim 1500^{\circ} \mathrm{C}$ て は 2〜6 時間でほとんど完全に還元が終ることがわかる。第 2 図 は第 1 図と同じ加熱速度の場合の焼成時間と結合炭素量との関係

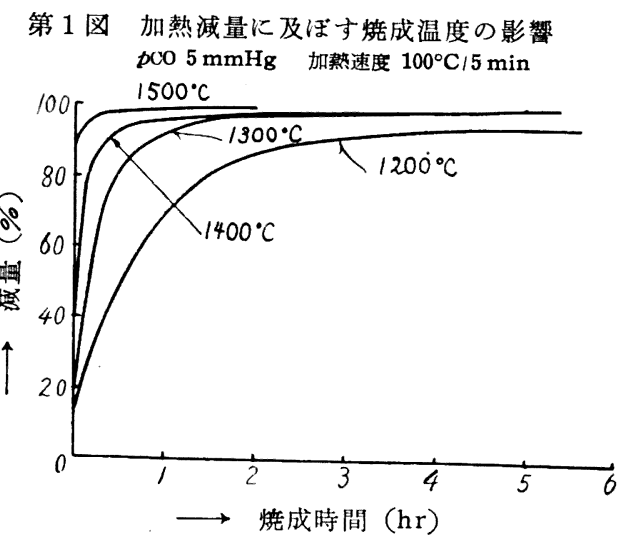

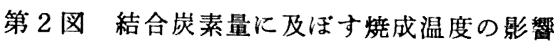
$p c 05 \mathrm{mmHg}$ 加慗速度 $100^{\circ} \mathrm{C} / 5 \mathrm{~min}$

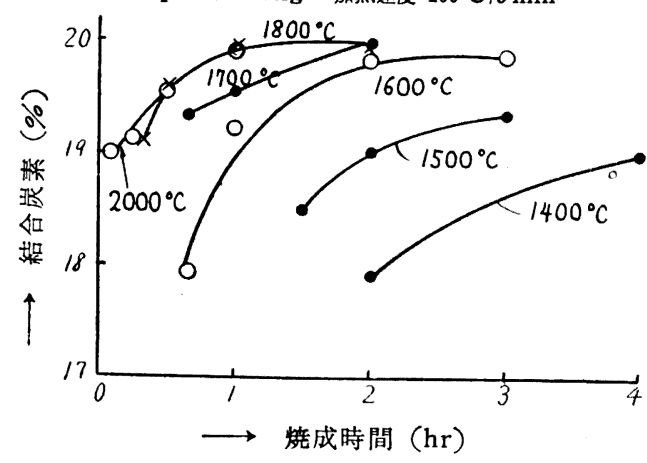

を表わしている。第 $1 ， 2$ 両図を比較することによりほとんど完 全に還元が終っても結合炭素量は TiC の理論值より少なく，焼 成温度が低いほど理論值との開きが大きいことがわかり，これは 反応生成物中に $\mathrm{TiC}-\mathrm{Ti}$ の固溶体 ${ }^{4,9}$ として $\mathrm{Ti}$ が存在すること を示している。

第 3，4 両図は加熱减量に及ぼす加熱速度の影響を示す。両図 において $\mathrm{A}, \mathrm{B}$ 抢よびCは堿量がほとんど等しい還元の初期の点 を示し，D， G はそれぞれ減量がほとんど理論值に相当する点を 示している。また第 3 図の $100^{\circ} \mathrm{C} / 5 \mathrm{~min}$ の曲線は所定速度で $\mathrm{E}$ $\left(1700^{\circ} \mathrm{C}\right)$ まで温度を上昇したのち減量が理論值に相当する $\mathrm{D}$ 点 までその温度に保ったものであり,この曲線でEからDに達する まで 60 90 分を要した。第 4 図の両曲線は所定速度で $2000^{\circ} \mathrm{C}$ まで温度を上昇したときの曲線であり，この5ち $150^{\circ} \mathrm{C} / \mathrm{min} の$ 曲線は $2000^{\circ} \mathrm{C}$ のF点に達してもなお減量は理論值に達せず, $2000^{\circ} \mathrm{C}$ に約 $30 \sim 40$ 分保つことによって理論值に相当する $\mathrm{G}$ 点

8) H.Krainer, K. Knopicky, Gmelins Handbuch der anorganischen Chemie, 8 Auflage, Titan, S. 369 (1951).

9) E. Beljakova, A. Komar, V. Michajlov, Gmelins Handbuck der anorgnaischen Chemie, 8 Auflage, Titan, S. 368 (1951). 


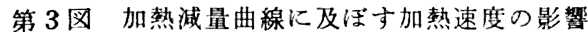
p co $5 \mathrm{mmHg}$

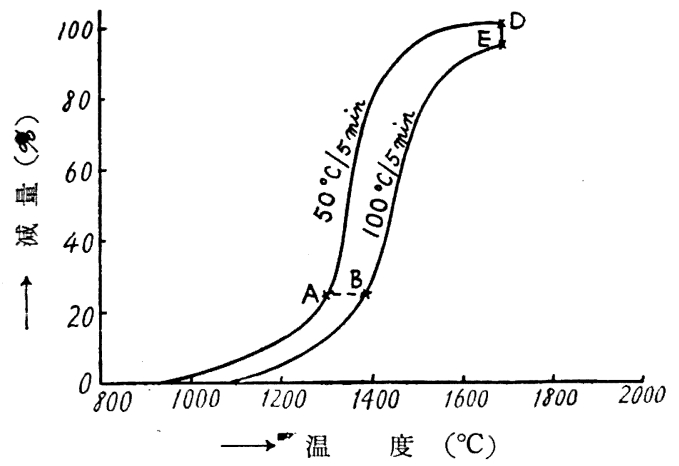

第 4 因加熱減量曲線に及ぼす加熱速度の影響 pCO $5 \mathrm{mmHg}$

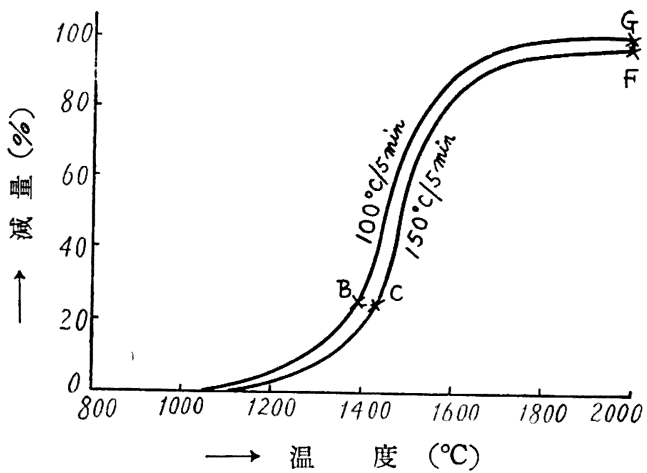

に達した。第 3 図から $50^{\circ} \mathrm{C} / 5 \mathrm{~min}$ の曲線に沿ってAからDまで 還元が進むには約 40 分しかかからないが, $100^{\circ} \mathrm{C} / 5 \mathrm{~min}$ の曲線 に沿って $\mathrm{B} \rightarrow \mathrm{E} \rightarrow \mathrm{D}$ なる径路を通ると 70〜100 分を要すること がわかる。同様に第 4 図から $100^{\circ} \mathrm{C} / 5 \mathrm{~min}$ の曲線の $\mathrm{B} \rightarrow \mathrm{G}$ なる 経過には $30 \sim 40$ 分でたりるが, $150^{\circ} \mathrm{C} / 5 \mathrm{~min}$ の $\mathrm{C} \rightarrow \mathrm{F} \rightarrow \mathrm{G}$ の径 路を通ると 50〜60 分を必要とする。ここで試料表面と温度測定 点との間には厚さ約 $2 \mathrm{~mm}$ の黒鉛板があるのみであり, 試料の 厚さも 13 14 mm の小さなものであるから, 温度測定点と試料 との間の温度差は加熱速度によって变化はするが大きな值とは考 えられない。また第 3,4 両図の $\mathrm{A}, \mathrm{B}$ およびCの 3 点に相当 するときの試料の真の温度は $\mathrm{A}<\mathrm{B}<\mathrm{C}$ の順に高いことは確実で あるので, 加熱速度の異なる 3 種の加熱减量曲線にそってそれぞ れ $\mathrm{A}, \mathrm{B}$ およびCの状態から少なくとも同一時間経過した後の 陚料の真の温度は加熱速度が速い場合ほど高温になっていると考 えられる。したがって $\mathrm{A} \rightarrow \mathrm{D}$ よりも $\mathrm{B} \rightarrow \mathrm{E} \rightarrow \mathrm{D}$ なる経過に, ま た $\mathrm{B} \rightarrow \mathrm{G}$ より $\mathrm{C} \rightarrow \mathrm{F} \rightarrow \mathrm{G}$ なる变化に多くの反応時間と要するこ

第 5 図 結合炭素量に及ぼす加熱速度の影響

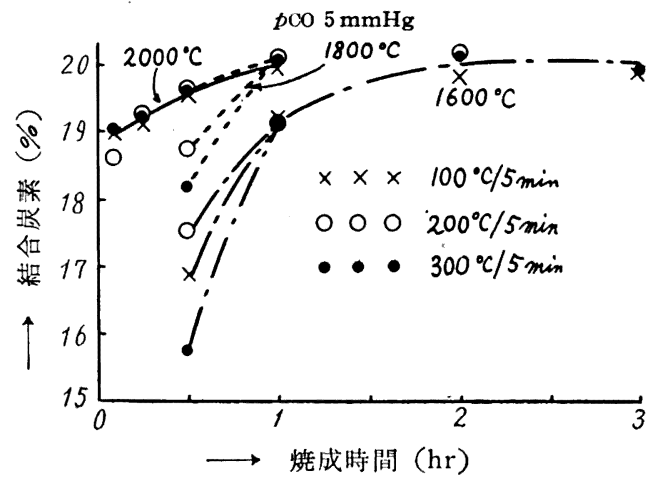

とは加熱速度が速いほど還元反応が遅いことを示している。

第 5 図は結合炭素量に及ぼす加熱速度の影響を示す。この結果 から $1600 \sim 1800^{\circ} \mathrm{C}$ では，焼成時間が短い間は，加熱速度が遅い 方が結合炭素量が多くなっているが，反応が平衡に達するまでの 所要時間は加熱速度によってほとんど影響されないことが判明す る。この結果を第 $3 ， 4$ 両図の結果と対照し，また第 1,2 両図 の結果をあわせて考えると次のように推定される。すなわち加熱 速度が遅いときは比較的低温で，かつ比較的短時間で還元が進む が, $\mathrm{TiO}+\mathrm{C}=\mathrm{Ti}+\mathrm{CO}$ のような反応によって生成した $\mathrm{Ti}(\mathrm{TiC}$ $\mathrm{TiO}-\mathrm{Ti}$ の固溶体)が $\mathrm{TiC}$ にならず，その $\mathrm{Ti}$ のほとんどが $\mathrm{TiC}$ になるまでには還元が完了してから後になお相当の反応時間を要 するものであろう。一方，加熱速度が速いときは還元が十分進ま ない中に高温に達するので, 比較的高温になっても $\mathrm{TiO}$ が存在 し，それが $\mathrm{TiO}+2 \mathrm{C}=\mathrm{TiC}+\mathrm{CO}$ のよ5に $\mathrm{Ti}$ を経ないで $\mathrm{TiO}$ から直接 $\mathrm{TiC}$ になる割合が多く，そして $\mathrm{TiO}$ から直接 $\mathrm{TiC} に$ なる反応は $\mathrm{Ti}$ までの還元より反応が遅いものと考えられる。結 局 $\mathrm{TiO}_{2} \rightarrow \mathrm{TiO} \rightarrow \mathrm{Ti} \rightarrow \mathrm{TiC}$ なる径路を経て $\mathrm{TiC}$ ができるときの 全所要時間と $\mathrm{TiO}_{2} \rightarrow \mathrm{TiO} \rightarrow \mathrm{TiC}$ なる径路のときの全所要時間と

第 6 図 結合炭素量に及ぼす配合比の影響 がほぼ等しくなる pCO $5 \mathrm{mmHg}$

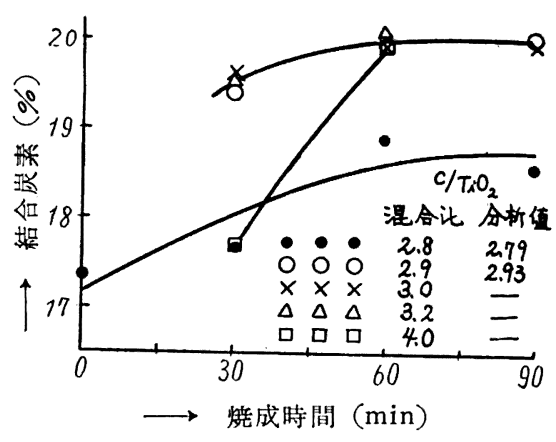

第7図遊離炭素量に及汪す配比合の影短

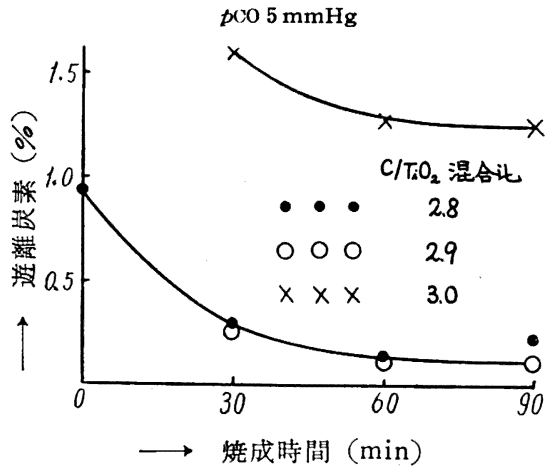

ものであろ

Krainer ${ }^{10)}$ らK よると $\mathrm{TiO} \rightarrow \mathrm{TiC}$ なる反応は $\mathrm{TiO}$ 中のOが直接 $\mathrm{C} に$ よって置換される と主張しているよ らであるが, 前述 の $\mathrm{TiO}$ から直接 $\mathrm{TiC}$ が生成する という考えと同様 なものではないか と考える。

第 6,7 両図は 結合炭素量および 遊離炭素量に及汪 す $\mathrm{C} / \mathrm{TiO}_{2}$ の配合 比の影響を示す。 第 6,7 両図から $\mathrm{C} / \mathrm{TiO}_{2}$ のモル比 を3より大きくし ても反応の速さに
はほとんど影響せず，未反応の遊離炭素を増加するのみであるこ とがわかる。Meerson ${ }^{11}$ (若干の $\mathrm{N}_{2}$ が存在するか, または真空 中では理論值より 2 3\% の過剩のCがなければ純粋な TiC が できないといっているが，CO 圧が $5 \mathrm{mmHg}$ の場合にはそのよ ラな事実は認められない。

第 8,9 両図には結合炭素量に及ぼす $\mathrm{CO}$ 圧の影響を示す。反

10) H. Krainer, K. Knopicky, Gmelins Handbuch der anorganischen Chemie, 8 Auflage, Titan, S. 359 (1951).

11) G. A. Meerson, Ann. sect. anal. phys. chim. Inst. chim. gén. (U.S.S.R.) 16, 197 (1943); Chem. Abst. 39, 4310 (1945). 


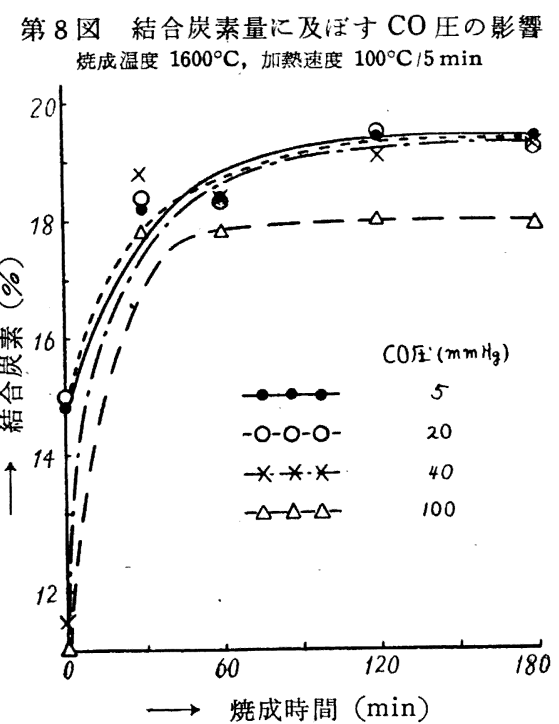

応温度が 1600

${ }^{\circ} \mathrm{C}$ の場合には 焼成時間がゼ口 のときには $\mathrm{CO}$ 圧が低いほど反 応が進んでい る。これは還元 が盛んな間は挾 散が反応を律速 しているためで あると考えられ る。しかるに焼 成時間が 30 分 になると $\mathrm{CO}$ 压 が $5 \sim 100 \mathrm{~mm}$ $\mathrm{Hg}$ のいずれの

第 9 図結合炭素量に及ぼす $\mathrm{CO}$ 圧の影響 烧成温度 $1800^{\circ} \mathrm{C}$, 加熱速度 $100^{\circ} \mathrm{C} / 5 \mathrm{~min}$

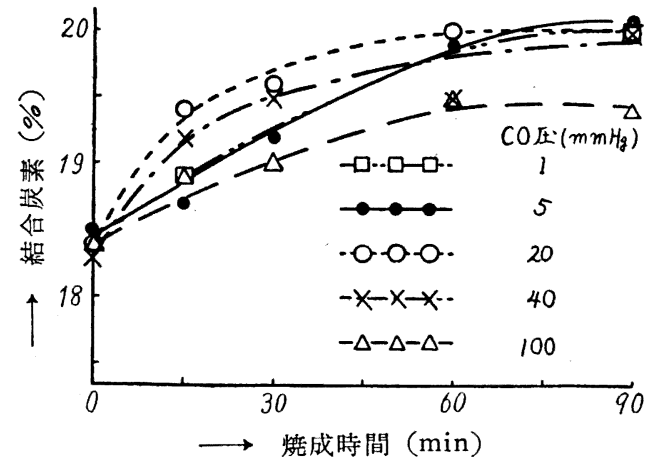

場合の焼成物も大差のない結合炭素をるつようになり, 結局本研 究の範囲では焼成時間が 0 30 分間で CO 圧が高いほど反応速 度が速いことになる。 $1800^{\circ} \mathrm{C}$ のときは，焼成時間がゼロのとき が $1600^{\circ} \mathrm{C}$ の場合の焼成時間 30 分程度のときと同じぐらいまで 反応が進んだ状態にあり，CO 圧が 1 100 mmHg のいずれの場 合すみな同じ程度まで反応が進んでいる。烧成時間が 15〜30 分 の間では CO 圧が $20 \sim 40 \mathrm{mmHg}$ のときに最も反応が進んでい ることがわかる。

Meerson4) らによると $\mathrm{TiC}$ の生成反応は $\mathrm{TiO}+2 \mathrm{C} \leftrightarrows \mathrm{TiC}+$ $\mathrm{CO}, \mathrm{TiO}+\mathrm{C} \rightleftarrows \mathrm{Ti}+\mathrm{CO}$, および $\mathrm{Ti}+\mathrm{C} \rightleftarrows \mathrm{TiC}$ なる平衡が成立 し, これらの条件の下で $\mathrm{TiO}+\mathrm{CO} \rightleftarrows \mathrm{Ti}+\mathrm{CO}_{2}, \mathrm{TiO}+3 \mathrm{CO} \rightleftarrows$ $\mathrm{TiC}+\mathrm{CO}_{2}, \mathrm{Ti}+2 \mathrm{CO} \rightleftarrows \mathrm{TiC}+\mathrm{CO}_{2}$ 执よび $\mathrm{C}+\mathrm{CO}_{2} \rightleftarrows 2 \mathrm{CO}$ のよう にCO が還元にあずかっていると推論しており，Assayage ${ }^{12)}$ は $840 \sim 1250^{\circ} \mathrm{C}$ の範囲で $\mathrm{TiO}_{2}$ は $\mathrm{CO}$ によって $\mathrm{TiO}_{1.89}$ ぐらい まで還元されることを示し，西村 ${ }^{13) ら は ~} 800 \sim 1400^{\circ} \mathrm{C}$ の範囲で $\mathrm{TiO}_{2}$ が $\mathrm{CO}$ によって還元されることを報告し，反応温度が高く なるにつれて還元が進むことを明らかにしている。これらの報告 をあわせて考えると $\mathrm{TiC}$ の生成反応過程で $\mathrm{CO}$ が還元を行って いることはほぼ確実である。このようにCO が還元に与っている とするならば, 前述した $1600^{\circ} \mathrm{C}$ の場合の烧成時間が 0 ３0 分の

12) P. Assayage, M. Dodé, R. Faivre, Campt. rend. 240, 1212 (1955).

13) 西村, 木村, Bull. Eng. Research Inst. Kyoto. Univ. 6, 19 (1954).
間では CO 圧が大きい㴗ど $\mathrm{TiC}$ の生成反応速度が速く, $1800^{\circ}$ の場合の焼成時間が 15 30 分の間では CO 圧が $20 \sim 40 \mathrm{mmHg}^{\circ}$ のときに最も反応が進んでいるとい5事実は次のよ5に解釈でき る。すなわち還元が盛んに進行している間はCO圧が大きくなる と反応生成ガスの拡散が㒓くなるので CO 圧が小さい汪ど反応が 速く進むが，還元が進むにつれて CO 圧の增加は反応を促進する ようになる。 $1600^{\circ} \mathrm{C}$ の焼成時間が 0〜30 分の間で $\mathrm{CO}$ 圧が大き いほど反応が速いのはこのような理由によるものであり，烧成時 間が 30 分をこえると平衡状態に近づくためにCO 圧の影響が見 られなくなる。 $1800^{\circ} \mathrm{C}$ の場合には焼成時間がゼロのときすでに 払散が反応を律速する段階をすぎており，平衡組成が同程度であ る CO 圧 1〜40 mmHg の範囲では 20 抢よび $40 \mathrm{mmHg}$ のと きの反応の進み方が速く, $100 \mathrm{mmHg}$ になると平衡状態におけ る結合炭素量が少ないために反応の進み方が $20 \sim 40 \mathrm{mmHg}$ の場 合より暹くなっているるのと考えられる。

なお第 8，9 両図の基礎になる分析值およびそれから求めた烧 成物の平衡組成を第 1 表に示す。この結果から CO 圧が 1 20 $\mathrm{mmHg}$, 反応温度 $1800^{\circ} \mathrm{C}$ に扎いて $\mathrm{TiO}_{2}$ と $\mathrm{C}$ の当量混合物を

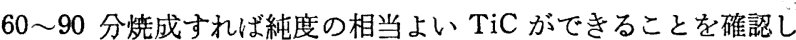
た。

第 1 表 結合炭素量（百分率）に及ぼす CO 圧の影響 (A) 孉成温度 $1600^{\circ} \mathrm{C}$

\begin{tabular}{ccccccc}
$\begin{array}{c}\text { 赎成時間 }(\mathrm{min}) \\
\mathrm{CO} \text { 圧 }(\mathrm{mmHg})\end{array}$ & 0 & 30 & 60 & 120 & 180 & 平衡組成 \\
\hline 5 & 14.8 & 18.2 & 18.4 & 19.4 & 19.4 & 19.4 \\
20 & 15.0 & 18.4 & 18.3 & 19.5 & 19.2 & 19.3 \\
40 & 11.5 & 18.8 & 18.4 & 19.1 & 19.3 & 19.2 \\
100 & 11.0 & 17.8 & 17.8 & 18.0 & 17.9 & 18.0
\end{tabular}

(B) 焼成温度 $1800^{\circ} \mathrm{C}$

\begin{tabular}{|c|c|c|c|c|c|c|}
\hline $\mathrm{COE}(\mathrm{mmHg})$ & 0 & 15 & 30 & 60 & 90 & 平衡組成 \\
\hline 1 & - & 18.9 & - & - & 20.0 & 20.0 \\
\hline 5 & 18.5 & 18.7 & 19.2 & 19,9 & 20.1 & 20.0 \\
\hline 20 & 18.4 & 19.4 & 19.6 & 20.0 & 20.0 & 20.0 \\
\hline 40 & 18.3 & 19.2 & 19.5 & 19.5 & 20.0 & 19.7 \\
\hline 100 & 18.4 & 18.9 & 19.0 & 19.5 & 19.4 & 19.5 \\
\hline
\end{tabular}

\section{総括}

純度の高い $\mathrm{TiC}$ をつるには真空電気师を使用するのが最す 有利であるとの見解の下に, $\mathrm{TiC}$ の生成反応過程に及ぼす種々 の反応条件の影響を系統的に検討した。すなわち $\mathrm{C} / \mathrm{TiO}_{2}$ のモル 比 2.8〜4.0 の混合物を真空電気师中に扣いて CO 圧 1 100 $\mathrm{mmHg}$, 温度 $1200 \sim 2000^{\circ} \mathrm{C}$, 加熱速度 $50 \sim 300^{\circ} \mathrm{C} / 5 \mathrm{~min}$ の範囲 の種々な条件で焼成し, 加熱減量曲線抢よび焼成物の結合炭素量 の測定を行い， $\mathrm{TiC}$ の生成反応過程について検討した。またあ わせて 1600 打よび $1800^{\circ} \mathrm{C}$ に打ける焼成物の平衡組成を求めた。 その結果焼成温度が低いときは焼成による减量が理論值の $100 \%$ に達しても生成物中には $\mathrm{Ti}$ が $\mathrm{TiC}-\mathrm{Ti}$ の固溶体として存在す ることを再確認するとともに, 焼成の際の温度上梨速度によって 反応径路に変化が起り, 加熱速度が速いときは $\mathrm{TiO}_{2} \rightarrow \mathrm{TiO} \rightarrow \mathrm{TiC}$ なる径路を通る割合が多く，加熱速度が遅い時は $\mathrm{TiO}_{2} \rightarrow \mathrm{TiO} \rightarrow$ $\mathrm{Ti} \rightarrow \mathrm{TiC}$ のように反応が進み易いという見解を明らかにした。 さらに CO 圧が $20 \sim 40 \mathrm{mmHg}$ のときに反応が速く進もことが わかり，それは $\mathrm{CO}$ が反応を促進するために生じたるのと推定で きた。なお CO 雾回気中で TiC を製造するには加熱速度はかな り速くしてよく, 反忘温度 $1800^{\circ} \mathrm{C}, \mathrm{CO}$ 圧 $1 \sim 20 \mathrm{mmHg}$, 焼成 
時間 60９0 分で純度のよい TiC がえられる。

(昭和 31 年 4 月, 日化, 化学機械連合年会講演)

本研究の遂行に当って当所部長鈴木基博士より終始御愁篤な御
指導を賜わった。酸化チタンは帝国化工から，アセチレンブラッ クはカーボンブラック想和会から頂戴した。厚く感謝する。

\section{ニッケル・スズ合金電極のアルカリ溶液における水素過電圧および酸素過電圧}

(昭 和 31 年 8 月 29 日 受 理)

传々木 熊三・杉山 幸 三*

\section{1. 緒言}

ニッケル・スズ合金電着は最近かなり用いられて来ているが, とくに合金組成原子比 1 対 1 に打いて良好な光沢電着物をうる。 この合金電着物は水素過電圧の高いスズとこれの低いニッケルと を合金させたものであるため, その水素過電圧は 2 成分単金属の 水素過電圧の中間値をとると推察されるが，定量的に合金組成と 水素過電圧との関係を知れば, この合金電着の各種材料への利用 に際して, 耐食性その他の電気化学的挙動の推測に役立つものと 考えられる。またこの合金電極はアルカリ溶液中で不働態化する ため化学的強度が大であるとされているが, 陽極的電解による影 響を知る目的で酸素過電圧をる測定した。

ニッケルとスズは冶金的には合金組成にしたがって数種の金属 中間化合物をつくることが知られているが，電着法でえられる合 金は NiSn に相当するヒ化ニッケル型合金を中心とする比較的狭 い合金組成範囲以外はえ難いとされている1)。著者らは陽極スズ の溶解を抑制する方法によってニッケルとスズの間の組成の数点 を取って合金電着を行い，6 N-カセイソーダ溶液中で両極過電压 を測定した。また, 極の表面積比を分極容量法によって求め, こ れを用いて電流密度と過電圧との関係を補正し, 合金組成と過電 压との関係をえた。

\section{2. 試料電極の作製}

i）浴組成 ·従来の報告1,2)によるとニッケル・スズ合金電着 浴は酸性フッ化アンモニウム, 塩化スズ, 塩化ニッケルより調製 されたものが最適とされているため著者らもこれを採用した。ス ズ含量 $0 \dot{\sim} 60 \mathrm{wt} \%$ の電着物を5るためには浴中の $\mathrm{SnF}_{4}{ }^{2-}$ 錯イ オン濃度が著しく低いことを要求され，バッチ式補充法によって は円滑な電着を継続し難いため著者らは $\mathrm{SnF}_{4}{ }^{2-} イ$ イオを含まな い $\mathrm{Ni}^{2+}$ イオンのみの浴から出発して, 陽極スズおよび陽極ニッケルへの電流の 配分を適当に選んで，平衡浴組成に近つ くのを数回の電着物分析によって確認し た後, 試料電極を電着法で作製した。100 \% スズに近くなると電着状態が悪化し， 酸性フッ化アンモニウム浴からは適当な 陚料がえられなかったため分析用金属ス
ズを融解して成型した。

ii）メッキ槽，雷㿡操作 フッ化物浴であるためメッキ槽にグ ッタペルカを使用した。その略図を第 1 図に示す。陽極は $0.8 \mathrm{~cm}$ 第 1 図メ.ッキ装置 平方の断面を有する長さ $6 \mathrm{~cm}$ の

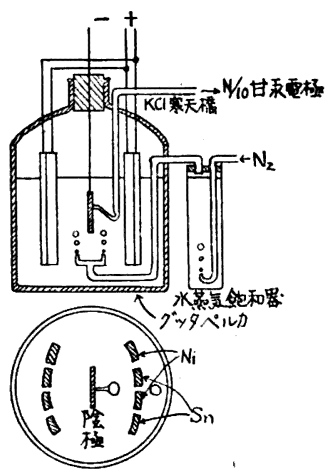
棒状ニッケルおよびスズをそれぞ れ 4 本ずつ用い，第 1 図のごとく 中央の陰極への影響を均一にする ように配置した。ニッケル陽極の 溶解は問題とならなかったが，ス ズ陽極はしばしば局部電池形成の ため過大に溶解する傾向があるた め，とくに塩化ビニルで極の大部 分を被覆し, 陽極電流の大小に応 じて 1 本のスズ陽極当りの露出面 積を $0.1 \sim 1.0 \mathrm{~cm}^{2}$ 程度に変化さ せ, 電着時間中以外は陽極を引上げた。この実験ではかきまぜが とくに重視され, 機械的かきまぜは材料の腐食のため適当でな く,ガスかきまぜではガラス管内外面に塩化ビニル被覆すればか なりよく腐食に耐え，ガスに窒素を選べば $\mathrm{Sn}^{2+} \rightarrow \mathrm{Sn}^{4+}$ を奶げる からこの点でも好適であった。陰極は分析用には白金電極, 試料 電極にはニッケルメッキ鉄板を用いた。その大きさは $1.5 \times 1.5$ $\mathrm{cm}^{2}$, 厚み $0.1 \mathrm{~cm}$ で試料電極は上辺中央部に幅 $0.2 \mathrm{~cm}$ の柄部 を残し、これに銅線を付し，ビニル被覆を施した。電着物分析は 白金上に電着したものを熱濃塩酸で溶解し濃硝酸を加えて乾固し 再び熱水に溶解し, 酢酸・酢酸ソーダを加えて緩衝溶液とし, 沈 殿を口過し，ついでオキシン法臭素酸カリ容量法でニッケルを分 析し電着重量から差引いてスズの量を算出した。

iii）雷着結果 電着条件抢よび電着物組成，性状等をまとめ て第 1 表に示す。

第 1 表 電着条件, 電着物組成, 性状

\begin{tabular}{|c|c|c|c|c|c|c|c|c|c|c|}
\hline $\begin{array}{l}\text { 第極 } \\
\text { 番号 }\end{array}$ & $\begin{array}{l}\mathrm{SnCl}_{2} \cdot \\
2 \mathrm{H}_{2} \mathrm{O}\end{array}$ & $\begin{array}{l}\text { 浴 組 } \\
\mathrm{NiCl}_{2} \cdot \\
6 \mathrm{H}_{2} \mathrm{O}\end{array}$ & $\frac{\mathrm{x}(\mathrm{g} / \mathrm{l})}{\mathrm{NH}_{4} \mathrm{HF}_{2}}$ & $\mathrm{NaF}$ & $\mathrm{pH}$ & $\begin{array}{c}\text { 浴 温 } \\
\left({ }^{\circ} \mathrm{C}\right)\end{array}$ & $\begin{array}{r}\text { 䉓流密㟬 } \\
\left(\mathrm{A} / \mathrm{dm}^{2}\right) \\
\end{array}$ & $\begin{array}{c}\text { 䉓流配分比 } \\
\mathrm{Sn}: \mathrm{Ni}\end{array}$ & $\begin{array}{c}\text { 推定 } \mathrm{Ni} \\
\text { 含 } \\
(\%)\end{array}$ & 肉眼的表面状態 \\
\hline 27 & 0 & 200 & 35 & 28 & 1.8 & 65 & 0.5 & $0: 10$ & 100 & 鋉光 沢 \\
\hline 9 & $"$ & 300 & $"$ & $"$ & $"$ & 60 & 1.0 & $1: 9$ & 85 & 灰黑色粗面 \\
\hline 10 & $"$ & " & " & $"$ & $"$ & $"$ & $"$ & $2: 8$ & 71 & 同上 \\
\hline 14 & $"$ & $"$ & $"$ & $"$ & $"$ & $"$ & $" \prime$ & $4: 6$ & 59 & $\begin{array}{l}\text { 兏急, 部分的に白 } \\
\text { 銀色沙 }\end{array}$ \\
\hline 20 & 50 & 20 & $"$ & $"$ & $"$ & 65 & 0.5 & $0: 10$ & 34 & 白銀色光沢 \\
\hline 17 & 21 & 180 & 15 & 11 & $"$ & 60 & 3.5 & $0: 10$ & 23 & $\begin{array}{l}\text { 同上，僅かに樹枝 } \\
\text { 吠突起 }\end{array}$ \\
\hline
\end{tabular}

各電極に通じた電気量は電流密度のいかんを問わず 18 クーロ ン $/ \mathrm{cm}^{2}$ とした。第 9 行の電流配分比の中で No. 20 拈よび No. 17 の電極に対しては浴中に十分の $\mathrm{Ni}^{2+}$ および $\mathrm{SnF}_{4}{ }^{2-}$ が存在 するから，陽極からの溶解による浴組成への影響は小さいと考え
* 名古屋大学工学部応用化学教室: 名古屋市千種区不老町.

1) J.W.Cuthertson, N. Parkinson, J. Electrochem. Soc. 100, 107 (1953).

2) N. Parkinson, U.S.P. 2,658,866, Nov. 10 (1953). 